\title{
MENTAL ACTS OF MATHEMATICALLY GIFTED STUDENTS WHEN SOLVING FRACTIONS PROBLEMS
}

\author{
Trisno Ikhwanudin* \\ PPPPTK TK dan Kemendikbudristek \\ *Email: trisno.ikhwanudin@gmail.com
}

Diterima: 04 Juni 2021. Disetujui: 18 Juni 2021. Dipublikasikan: 31 Juli 2021

\begin{abstract}
ABSTRAK
Berbagai variasi peserta didik dengan kebutuhan khususnya dapat ditemukan di kelas. Salah satu kelompok peserta didik dengan kebutuhan belajar berbeda adalah peserta didik gifted. Artikel ini berfokus pada peserta didik yang memiliki potensi giftedness dalam matematika. Tujuan penelitian adalah memperoleh gambaran bagaimana aksi mental peserta didik yang memiliki potensi kecerdasan istimewa dalam matematika ketika menyelesaikan masalah pecahan. Pendekatan penelitian yang digunakan adalah kualitatif. Responden penelitian ini adalah dua orang peserta didik kelas 7 SMP di Provinsi Jawa Barat, Indonesia. Instrumen penelitian berupa tes, observasi dan wawancara. Data dikumpulkan dengan memberikan tes, observasi, dan wawancara. Data dianalisis dilakukan dengan grounded theory dengan cara coding dan constant comparison. Hasil penelitian menunjukkan empat jenis mental acts, yakni interpreting, explaining, problem-solving, dan inferring. Hasil penelitian ini dapat digunakan sebagai antisipasi didaktik ketika guru mengajarkan konsep pecahan bagi peserta didik dengan potensi kecerdasan istimewa dalam matematika, dengan harapan agar tercapai hasil belajar yang optimal.
\end{abstract}

Kata kunci: aksi mental, siswa berbakat matematika, pecahan

\begin{abstract}
In the classroom, we will find various types of students with their special learning needs. One group of learners who have different learning needs are gifted students. The paper will focus on the study of mathematically gifted students. This research aims to obtain a description of the mathematically gifted students' mental acts when solving fractions problems. The research approach was qualitative. The respondents were two students of the 7th graders in junior high school, in the West Java Province, Indonesia. The data were collected through paper and pencil measure, observation, and interview. The data were analyzed by grounded theory with coding and constant comparison. The results show four types of mental acts, those are interpreting, explaining, problem-solving, and inferring. The results of this study can be made as one of didactic anticipation when teachers teach the concept of fractions to the mathematically gifted student. These findings are significant to be considered by the teacher when teaching the mathematically gifted student. Teachers should anticipate how students think when they teach gifted students. So that teachers and students can achieve optimal learning outcomes.
\end{abstract}

Keywords: Mental Acts, Mathematically Gifted Students, Fractions

\section{Introduction}

We will find various types of students with their special learning needs in the classroom. One group of learners who have different learning needs is gifted students. Learning for gifted students should be tailored to their gifted characteristics. Gifted students generally have the following characteristics: remarkable memories, detailed observers, deep curiosity, creativity, and the ability to learn teaching materials quickly and precisely with just a little practice and repetition (Piirto, 2007).

Some experts have proposed the definition of giftedness. Renzulli (1986) states that giftedness is an interaction between the following three factors: above average ability, high creativity, and commitment to completing tasks. Gagne (2015) stated that giftedness is a remarkable natural ability in the intellectual domain (residing on 10\% highest position in the population). 


\section{Range: Jurnal Pendidikan Matematika Vol. 3 No. 1 Tahun 2021 Trisno Ikhwanudin}

In mathematics education, some scholars and institutions have proposed the definition of giftedness in mathematics. Krutetskii (1976) states that mathematical giftedness is a unique aggregate of mathematical abilities that opens up the possibility of successful performance in a mathematical activity. Based on Kapnik (in Singer, et al, 2016) mathematical giftedness is characterized by the following characteristics: remembering mathematical facts, structuring mathematical facts, mathematical sensitivity and mathematical fantasy, transferring mathematical structures, intermodal transfer, reversing lines of thoughts. According to Mann (2006) research, mathematically gifted students can be identified with the performance of students in the classroom, test scores, and recommendations. NCTM states mathematically gifted student with another language, i.e. mathematically promising student. NCTM introduces the term mathematical promising student characterized by its maximal abilities, motivations, beliefs, experiences, and opportunities in mathematics (Sheffield, 1999).

Even though, learning that suits the needs of mathematically gifted students is very important to explore their potency, studies that examine the learning of mathematically gifted student are limited (Leikin, 2011).

Taking into account all the considerations above, the problem of this research is how mathematically gifted student's mental acts when solving fraction problems. In this study, we aim to obtain a description of the mathematically gifted students' mental acts when solving fractions problems with their ways of thinking and ways of understanding.

The material used in this study is fractions. According to Clarke, et al. (2010: 15) the definition of fractions is as follows:

"A fraction is a symbolic expression that represents the results of two numbers $\frac{a}{b}$ (with $b$ not equal to zero). So, all rational numbers expressed in form $\frac{a}{b}$ are fractions, but rational numbers 1.45 are not fractions. The 1.45 rational number can be called a fraction if it is written $\frac{145}{100}$. So, all rational numbers can be written as fractions, but there are some important fractions that are not rational numbers, for example: $\frac{\pi}{4}$ or $\frac{\sin \frac{\pi}{4}}{2}$."

In this study, students and the teacher use fractions handout which adapted from Cramer et al (2009); the handout approach was called Lesh Multiple Translation Model (Cramer, 2003). To analyze the students' thinking, we used Harel's theory: Mental Act, Ways of Understanding and Ways of Thinking (Harel, 2008a). This theory is chosen because the researchers want to know the student's way of thinking when they learn fractions in the inclusive classroom.

Mental Acts, Ways of Understanding and Ways of Thinking

According to Harel (2008a), mathematics is the set of ways of understanding (WoU) and ways of thinking (WoT). WoU is the product of mental acts; it consists of axioms, definitions, theorems, proofs, problems, and solutions. WoT is the characteristics of mental acts; it consists of all the ways of thinking that used to produce WoU. Harel (2008b) illustrated the relationship between mental act, WoT, and WoU with the following figure.

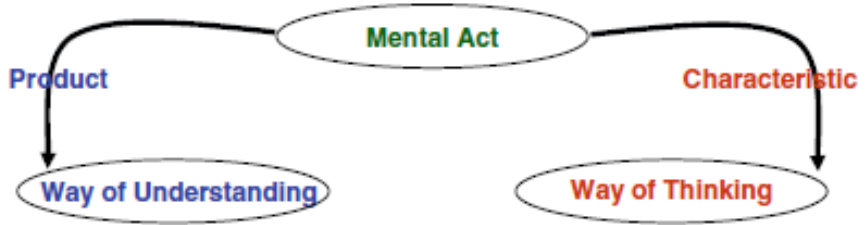

Figure 1. The triad of mental act, WoU, and WoT 


\section{Range: Jurnal Pendidikan Matematika Vol. 3 No. 1 Tahun 2021 Trisno Ikhwanudin}

In Figure 1., Harel (2008a) stated that a mental act is a characteristic of thinking in line with the problems encountered; a WoU is a specific cognitive product of the mental act performed by an individual; a WoT is the cognitive characteristic of the mental act. The cognitive characteristics of the mental act are inferred from the observation of the WoU.

Furthermore, Harel (2008a) suggested that when analyzing students' WoU and WoT, it starts from a mental act being observed, consider the type of cognitive product (WoU), and tries to find the common cognitive nature between the WoU. Every character that found is the WoT associated with the mental act.

\section{Research Method}

This research used a qualitative approach. This study used a case study with the single-case (holistic) design (Yin, 2009). The case study method is used to describe field findings related to the research problem formulation, i.e., how mathematically gifted student's mental acts when solving fractions problems. The data collection techniques used in this study are paper and pencil measure (test), observation and interview. The data were analyzed by grounded theory, with coding and constant comparison (Gall, Gall, \& Borg, 2010).

\section{Participant}

This research is conducted in a Junior High School in West Java, Indonesia, with two mathematically gifted students in grade 7 as a respondent. The student is selected based on test results, observation and teacher recommendation (Mann, 2006). The two students get the highest score during the test. They are two students who have high motivation to complete all tasks. The teacher also recommended them as a mathematically gifted student. The students are given research instruments, then their work is analyzed using Harel theory. We call the two students with student A and student B; student A is 12-year-old boy, student B is 12-year-old girl.

\section{Instruments}

The test instruments used in this study are as follows:

Table 1. The Test Instruments

\begin{tabular}{ccc}
\hline No & \multicolumn{1}{c}{ Problems } & \multicolumn{1}{c}{ Indicator } \\
\hline 1 & $\begin{array}{l}\text { Draw the following fractions: } \frac{1}{2} \text { and } \frac{2}{5} \text { with } \\
\text { two different ways. }\end{array}$ & $\begin{array}{l}\text { Students can understand the representation } \\
\text { of fractions in various forms }\end{array}$
\end{tabular}


2 Check which fraction images are larger:
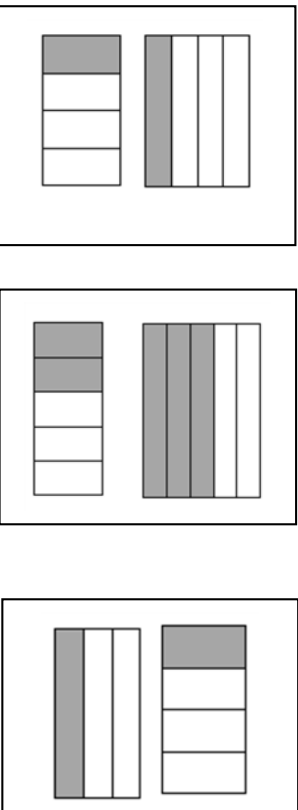

3
a. Explain which one is larger: $\frac{1}{2}$ or $\frac{2}{3}$
b. Explain which one is larger: $\frac{2}{3}$ or $\frac{3}{4}$

4 Write down your way to find 2 fractions which are equal $\frac{1}{2}$ ?

5 Complete the following problems with the steps.
a. $\frac{1}{3}+\frac{1}{3}=$
b. $\frac{1}{3}+\frac{1}{2}=$

6 Complete the following problems with the steps.
a. $\frac{4}{5} \times \frac{1}{3}=$
b. $\frac{9}{4} \div \frac{3}{5}=$

7 Susi ran $\frac{2}{5} \mathrm{~km}$ on Monday. On Tuesday, Susi ran $\frac{3}{7} \mathrm{~km}$. Explain how many kilometers $(\mathrm{km})$ Susi ran on both days?

8 Mrs. Wati bought $1 \mathrm{~kg}$ of cooking oil. In the road, the cooking oil was spilled. It turns out that the remaining cooking oil is $\frac{1}{3} \mathrm{~kg}$. How many $\mathrm{kgs}$ of cooking oil is
Students can understand the fraction comparisons in various forms of representation
Students can understand fraction comparisons

Students can understand the equal fractions

Students can perform the addition operation of fractions

Students can perform the multiplication and division operation of fractions

Students can understand the operation of fractions addition in a word problem

Students can understand the operation of fractions subtraction in a word problem 
spilled?

9 Which fractions are larger than $\frac{3}{4}$ of 5 tons or $\frac{5}{6}$ of 5 tons?

10 A tailor receives $\frac{2}{3} \mathrm{~m}$ of white cloth with floral motifs to make a handkerchief.

Students can understand fraction comparisons in the form of multiplication fractions

Students can understand the operation of fractions division in a word problem Each handkerchief requires $\frac{1}{6} \mathrm{~m}$ of fabric. How many handkerchiefs can be made?

Some external experts have conducted content and construct validation of this instrument. This test instrument is given at the end of the learning session using the Indonesian national curriculum. The test indicator is the same as the fraction topic that has been studied by students. So, this test instrument evaluates the understanding of fraction material learned by the student.

Observations are carried out with the teacher when the student is working on the test. The purpose of this observation is to assess the student's commitment when working on test questions. While the interview was conducted on the teacher to get a recommendation that the student is mathematically gifted.

\section{Data Processing Methods}

In this study, we arrange the data as follows: the themes are mental acts, ways of understanding, and ways of thinking. The subthemes (category) of mental acts are interpreting, explaining, problemsolving, and inferring (the types of mental acts). The subthemes of ways of understanding are interpretation, explanation, solution, and inference, etc. (the types of ways of understanding). The subthemes of ways of thinking are a problem-solving approach, multiple interpretation strategies, etc. (the types of ways of thinking). We created a code for each students' answer; then the code is matched with the subtheme (category). For example, consider the student's answer below:

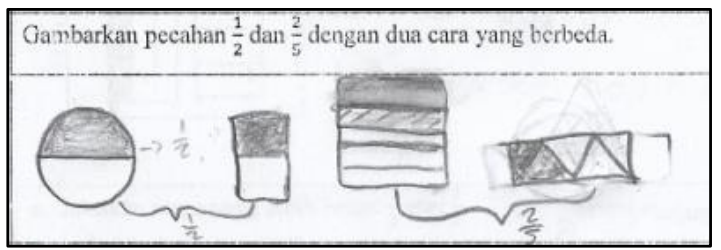

Figure 2. The student answer sheet

From Figure 2. we record figures as a code. We create a diagram that represents the interrelation between the code, subtheme, and theme as follows: 
CODE

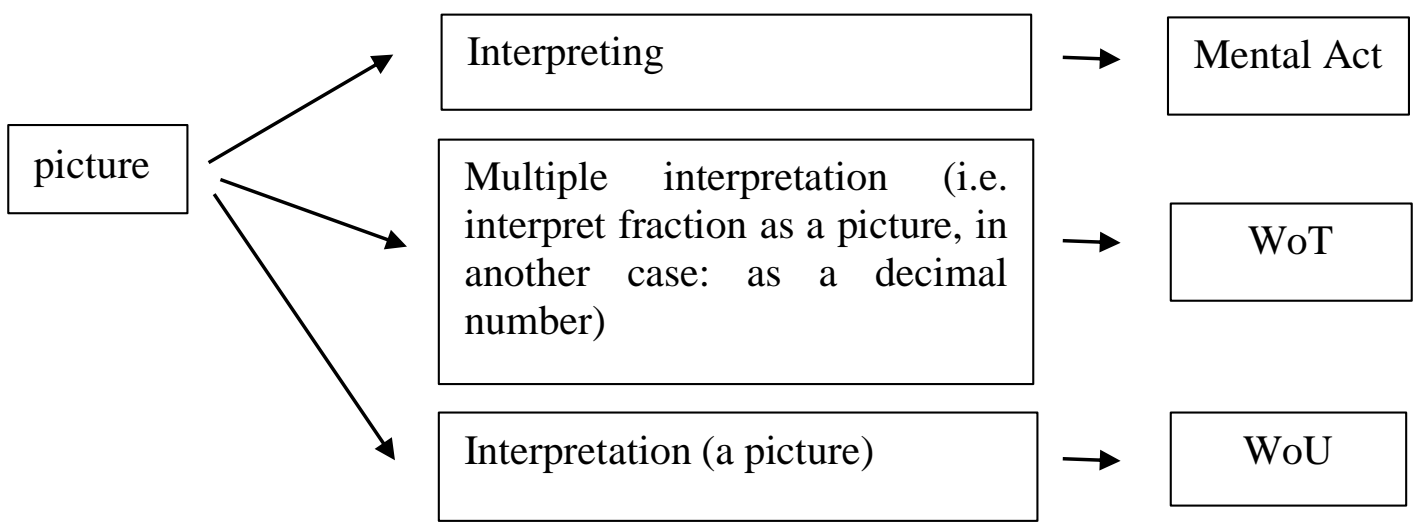

Figure 3. The interrelation between the code and the theme

In Figure 3., picture (code) corresponds to interpreting (subtheme) and mental acts (theme); picture (code) corresponds to multiple interpretations as a decimal number (subtheme) and ways of thinking (theme); picture (code) corresponds to interpretation (subtheme) and ways of understanding (theme).

\section{Research Result and Discussion}

After examining two mathematically gifted students, the analysis of mental acts is conducted. We call the two mathematically gifted students with student A and B.

\section{The mental acts of student $A$}

\section{Interpreting}

The first mental act that found in the analysis of student' answer is interpreting. Interpreting means explaining the meaning of information, a word, or an action. From the study of the student solution, we found some students who do mental act interpreting, as follows:

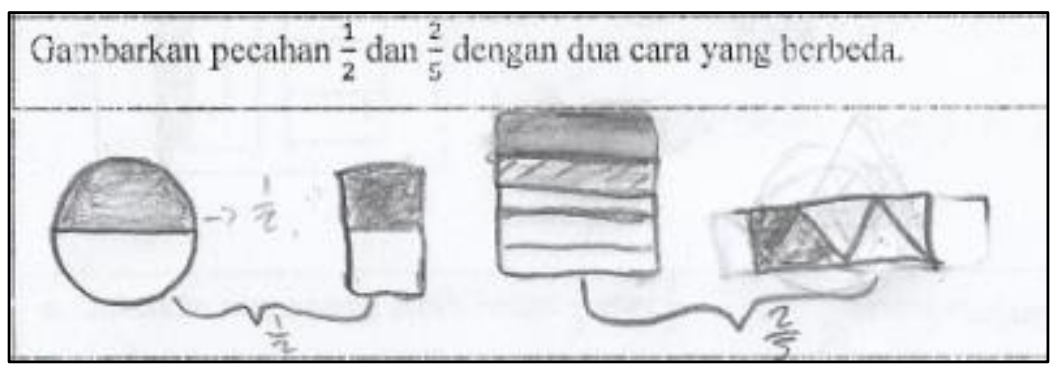

Figure 4. Mental acts of student A on interpreting

In Figure 4., the student is asked to describe fractions $\frac{1}{2}$ and $\frac{2}{5}$ in two different ways. In the student's answer, it appears that student A performs mental act interpreting by interpreting fractions $\frac{1}{2}$ and $\frac{2}{5}$ with shaded circle and rectangles.From the student answer, we can also identify the student's way of understanding which corresponds to mental act interpreting, that is interpretation. Interpretation is the 


\section{Range: Jurnal Pendidikan Matematika Vol. 3 No. 1 Tahun 2021 Trisno Ikhwanudin}

cognitive product of mental act interpreting. In this case, student A interpretation of fractions are circle and rectangles.

We can also recognize student's way of thinking which corresponds to mental act interpreting, that is multiple interpretations of fractions. Multiple interpretations of fractions is a cognitive characteristic of mental act interpreting. In this case, student A has multiple interpretations on fractions, that are fractions as circle and rectangles.

\section{Explaining}

The second mental act that found in the analysis of student' answer is explaining. Explaining is one form of human reasoning. Explaining means making ideas, situations, or issues clear to someone, by explaining them in more detail or by disclosing relevant facts or opinions. From the test result, student A performs a mental act explaining as follows:

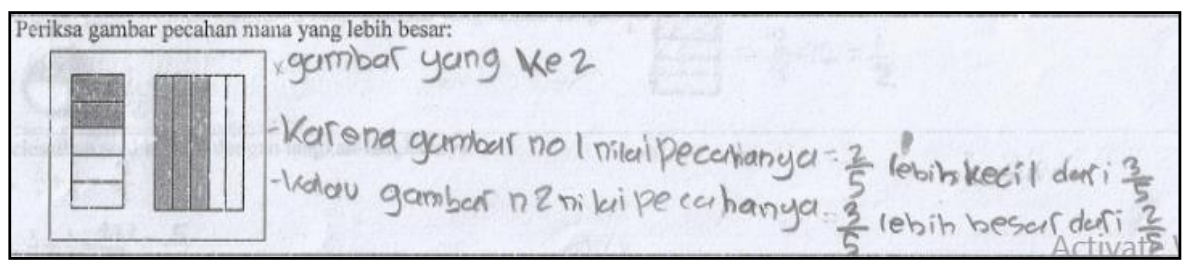

Figure 5. Mental acts of student A on explaining

Figure 5. shows that student A answer the question with a mental act explaining. The problem asks about which fraction representation image is larger. In the student sheet, it appears that students understand the problem and answer it by using mental act explaining. From the student answer, we can also identify the student's way of understanding, that is an explanation. The student's solution contains an explanation with good reason. The explanation is a cognitive product of mental act explaining.

We can also recognize student's way of thinking which corresponds to mental act explaining, that is the way of explaining (how to explain). How to explain is the cognitive characteristic of the mental act explaining. How to explain closely related to students' mathematical communication skills. Indicator of students' mathematical communication ability can be seen from: (1) ability to express mathematical ideas through oral, written, and demonstrate and visualize it; (2) ability to understand, interpret, and evaluate mathematical ideas both orally and in other visual forms; (3) ability to use terms, mathematical notations and structures to present ideas, describe relationships and situational models (NCTM, 1989).

In this case, student A performs explaining/expressing mathematical ideas through writing as a way of explaining.

\section{Problem-Solving}

The third mental act that found from the analysis of student answers is problem-solving. Problemsolving means the process of finding solutions for difficult or complex problems. From the analysis of student answers, we identify students A performs mental act problem-solving as follows:

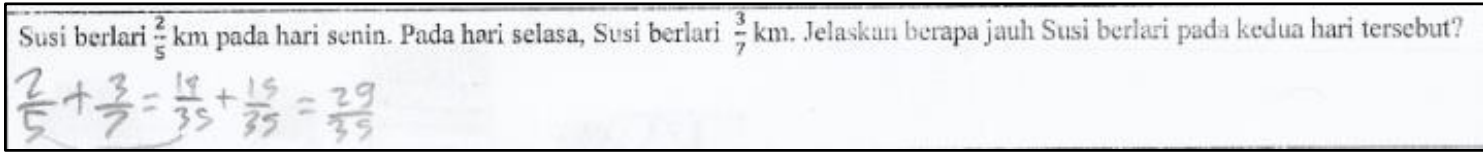

Figure 6. Mental act of student A on problem-solving

In Figure 6., to answer this word problem, student A performs mental act problem-solving by modeling the problem into a sum of fractions. Then, the student solved the fraction sum problem with 


\section{Range: Jurnal Pendidikan Matematika Vol. 3 No. 1 Tahun 2021 Trisno Ikhwanudin}

common denominator approach. Fractions $\frac{2}{5}$ changed to $\frac{14}{35}$, and $\frac{3}{7}$ changed to $\frac{15}{35}$. Then the student add up the two fractions and get the result $\frac{29}{35}$.

From the student answer, we can also identify the student's way of understanding which corresponds to mental act problem-solving, that is the solution. The solution is the cognitive product of mental act problem-solving.

We can also recognize student's way of thinking which corresponds to mental act problemsolving, that is the problem-solving approach. A problem-solving approach is a cognitive characteristic of mental act problem-solving. In this case, student A performs common denominator strategy as a problemsolving approach.

\section{Inferring}

The fourth mental act that found from the analysis of student answer is inferring. Inferring means to deduce (information) from evidence and reasoning, not from explicit statements. From the analysis of student answers, we identify student A performs mental act inferring as follows:

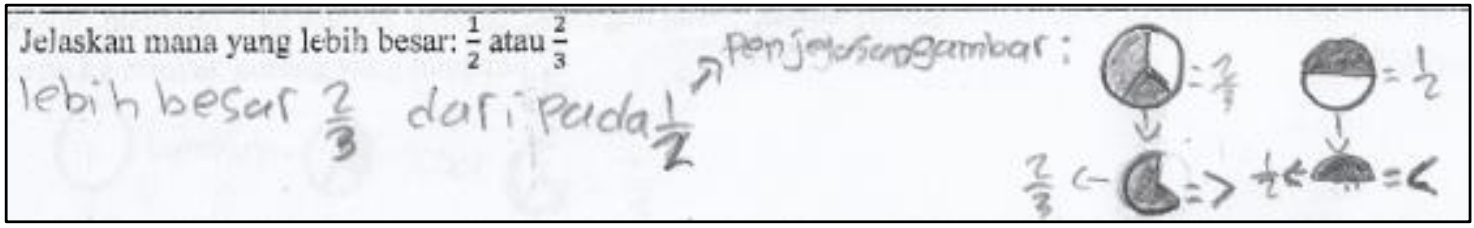

Figure 7. Mental act of student A on inferring

In Figure 7., student $A$ is asked which fractions are larger between $\frac{1}{2}$ and $\frac{2}{3}$. To answer this problem, student A does the reasoning by drawing circles that represent $\frac{1}{2}$ and $\frac{2}{3}$. He seems to take off the part that describes $\frac{2}{3}$ and $\frac{1}{2}$, and shows that $\frac{2}{3}$ more than $\frac{1}{2}$. Then student $\mathrm{A}$ infer that $\frac{2}{3}<\frac{3}{4}$.

From the student answer, we can also identify the student's way of understanding which corresponds to mental act inferring, that is inference. The inference is the cognitive product of mental act inferring.

We can also recognize student's way of thinking which corresponds to mental act inferring, that is how to draw an inference (conclusion). How to draw an inference is a cognitive characteristic of mental act inferring. How to conclude can be done with deductive and inductive reasoning (Harel, 2008b). In this case, student A performs deductive reasoning as a way to draw an inference.

\section{The mental acts of student $B$}

\section{Interpreting}

The first mental act found in the analysis of students' answer is interpreting. Interpreting means explaining the meaning of information, a word, or an action. We find student B performs mental act interpreting as follows:

\begin{tabular}{|l|l|l|l|}
\hline Gambarkan pecahan $\frac{1}{2}$ dan $\frac{2}{5}$ dengan dua cara yang berbeda. \\
\hline$\frac{1}{2}-$ & & \\
\hline
\end{tabular}




\section{Range: Jurnal Pendidikan Matematika Vol. 3 No. 1 Tahun 2021 Trisno Ikhwanudin}

Figure 8. Mental acts of student B on interpreting

In Figure 8., students $B$ is asked to describe fractions $\frac{1}{2}$ and $\frac{2}{5}$ in two different ways. In the student's answer, it appears that student B performs mental act interpreting by interpreting fractions $\frac{1}{2}$ and $\frac{2}{5}$ with shaded circle and rectangles. From the student answer, we can also identify the student's way of understanding which corresponds to mental act interpreting, that is interpretation. Interpretation is the cognitive product of mental act interpreting. In this case, student B interpretation of fractions is circle, square, and rectangles.

We can also recognize student's way of thinking which corresponds to mental act interpreting, that is multiple interpretations of fractions. Multiple interpretations of fractions is a cognitive characteristic of mental act interpreting. In this case, student B has multiple interpretations on fractions, that are fractions as circle, square, and rectangles.

\section{Explaining}

Explaining is one form of human reasoning. Explaining means making ideas, situations, or issues clear to someone, by explaining them in more detail or by disclosing relevant facts or opinions. From the test result, student B performs a mental act explaining as follows:

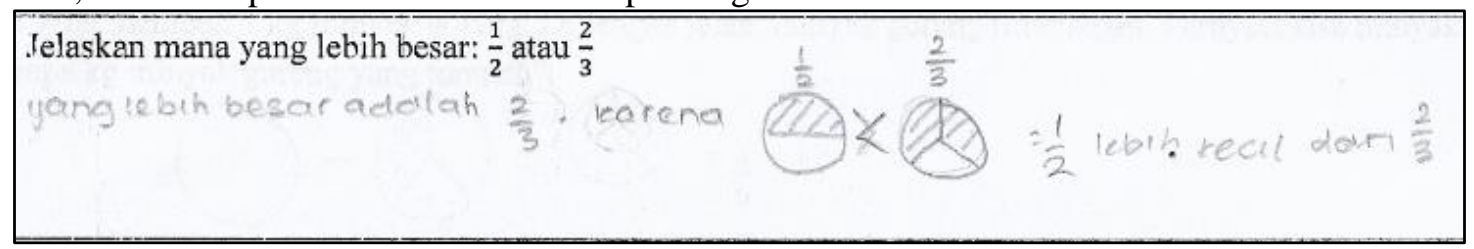

Figure 9. Mental acts of student B on explaining

Figure 9. shows a mental act explaining of student B. Student B is asked which fractions are larger between $\frac{1}{2}$ and $\frac{2}{3}$. In the student sheet, it appears that students B understand the problem and answer it by using mental act explaining; she explains that $\frac{2}{3}$ is larger, she uses the picture to explore her answer. The student's solution contains an explanation with the right reason.

From the student answer, we can also identify the student's way of understanding, that is an explanation. The explanation is a cognitive product of mental act explaining.

We can also recognize student's way of thinking which corresponds to mental act explaining, that is the way of explaining (how to explain). How to explain is the cognitive characteristic of the mental act explaining. In this case, student B performs explaining/expressing mathematical ideas through writing as a way of explaining.

\section{Problem-Solving}

The fourth mental act that found from the analysis of student answers is problem-solving. Problem-solving means the process of finding solutions for difficult or complex problems. From the analysis of student answers, we find students B performs mental act problem-solving as follows:

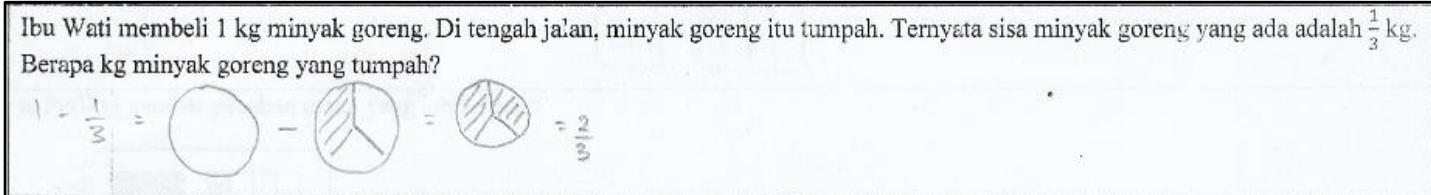

Figure 10. Mental act of student B on problem-solving

In Figure 10., to answer this word problem, student B performs mental act problem-solving by modeling the problem into a subtraction of fractions: $1-\frac{1}{3}$. Then, the student solved the fraction 


\section{Range: Jurnal Pendidikan Matematika Vol. 3 No. 1 Tahun 2021 Trisno Ikhwanudin}

subtraction problem with the pictorial approach. Fractions 1 changed to a circle, and $\frac{1}{3}$ changed to a circle divided three with one part shaded. Then student B draws a circle divided three with two-part shaded, and she writes $\frac{2}{3}$ as an answer.

From the student answer, we can also identify the student's way of understanding which corresponds to mental act problem-solving, that is the solution. The solution is the cognitive product of mental act problem-solving.

We can also recognize student's way of thinking which corresponds to mental act problemsolving, that is the problem-solving approach. A problem-solving approach is a cognitive characteristic of mental act problem-solving. Student B uses drawing a picture as a problem-solving approach.

\section{Inferring}

The third mental act that found from the analysis of student answers is inferring. Inferring means to deduce (information) from evidence and reasoning, not from explicit statements. We find student B performs mental act inferring as follows:

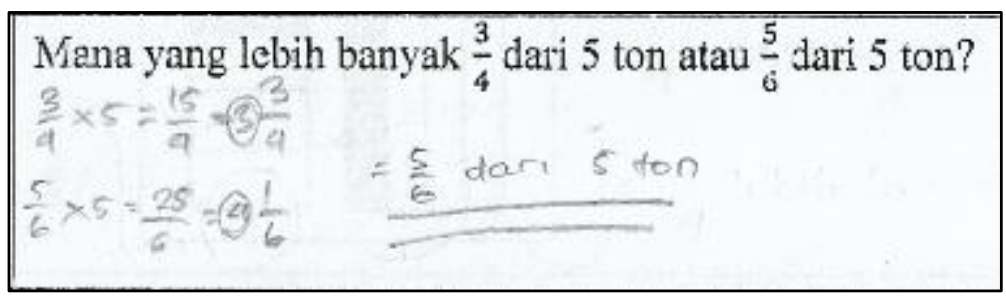

Figure 11. Mental act of student $B$ on inferring

In Figure 11., student B is asked which fractions are larger between $\frac{3}{4}$ of 5 tons and $\frac{5}{6}$ of 5 tons. To answer this problem, student $\mathrm{B}$ does the reasoning by performing fractions multiplication operation: $\frac{3}{4} \times$ $5=\frac{15}{4}=3 \frac{3}{4}$ and $\frac{5}{6} \times 5=\frac{25}{6}=4 \frac{1}{6}$. Then student B infer that $\frac{5}{6}$ of 5 tons are larger.

From the student answer, we can also identify the student's way of understanding which corresponds to mental act inferring, that is inference. The inference is the cognitive product of mental act inferring.

We can also recognize student's way of thinking which corresponds to mental act inferring, that is how to draw an inference (conclusion). How to draw an inference is a cognitive characteristic of mental act inferring. How to conclude can be done with deductive and inductive reasoning (Harel, 2008b). In this case, student B performs inductive reasoning as a way to draw an inference.

We summarize the findings of mathematically gifted students' mental acts in the following table:

Table 2. The summary of findings

\begin{tabular}{lll}
\hline Mental Acts & Ways of Understanding & Ways of Thinking \\
\hline Interpreting & Interpretation & Multiple interpretations \\
Explaining & Explanation & $\begin{array}{l}\text { how to explain/express mathematical } \\
\text { ideas through writing }\end{array}$ \\
Problem-solving & Solution & $\begin{array}{l}\text { Problem-solving approach: common } \\
\text { denominator approach, draw a picture }\end{array}$ \\
& &
\end{tabular}


approach

Inferring Inference how to draw inference: deductive reasoning, inductive reasoning

In Table 2., the findings of mathematically gifted students' mental acts are based on general observable features, although in reality, they can intersect each other.

In the result, we find four mental acts of mathematically gifted students; there are interpreting, explaining, problem-solving, and inferring. In the mental acts problem-solving, we identify many problems solving approach such as common denominator approach, invert multiple algorithms, change to a decimal approach, change to a percent approach, and draw a picture approach.

We find that the mathematically gifted students use more methods to solve problems if compared with her peers. One possible explanation for why this group of student can use more methods to solve problems is offered by Hong and Aqui (2004), which state that gifted children use more strategies to organize and transform information and use it more effectively. The research result also shows that mathematically gifted student uses drawing a picture approach to solve a problem, the students can visualize the mathematics problem. This finding is in accord with Presmeg (1986) view that the gifted student could visualize problems and relations.

We find that mathematically gifted student can show multiple representations when they solve problems. This finding is in line with Assmuss (2018) view that the mathematically gifted student can easily relate different form of representation and use differently represented information for solving a problem.

We also find that the gifted students successful in explaining their answer, i.e. making ideas, situations, or issues clear to someone, by explaining them in more detail or by disclosing relevant facts or opinions. This finding is in line with the study of Sriraman (2003) which stated that the gifted student could communicate effectively and verbalize in their problem explanation. Furthermore, we also identify that mathematically gifted student can use deductive reasoning to produce inference or conclusion when they solve problems. This finding is in accords with the study of Kurnaz (2018) which stated that gifted students' mathematics achievement is mostly related to their high mathematical reasoning skills.

\section{Conclusion}

In this research, we find four mental acts of mathematically gifted students; there are interpreting, explaining, problem-solving, and inferring. The results of this study can be made as one of didactic anticipation when teachers teach the concept of fractions to the mathematically gifted student. These findings are significant to be considered by the teacher when teaching the mathematically gifted student. Teachers should anticipate how students think when they teach gifted students. So that teachers and students can achieve optimal learning outcomes.

\section{References}

Assmuss, D. (2018). Characteristic of mathematical giftedness in early primary school age. In F.M. Singer (Eds.): ICME-Monographs, Mathematical creativity and mathematical giftedness: Enhancing creativities in mathematically promising student (pp. 145-168). Switzerland: Springer.

Clarke, C., Fisher, W., Marks, R., Ross, S., Zbiek, R.S. (2010). Developing Essential Understanding of Rational Numbers for Teaching Mathematics in Grades 3-5. Reston, VA: NCTM.

Cramer, K. (2003). Using a translation model for curriculum development and classroom instruction. In R. Lesh \& H. Doerr (Eds.): Beyond constructivism: Models and modeling perspectives on mathematics problem solving, learning, and teaching (pp. 449-464). Mahwah, NJ: Lawrence Erlbaum Associates 


\section{Range: Jurnal Pendidikan Matematika Vol. 3 No. 1 Tahun 2021 Trisno Ikhwanudin}

Cramer, K., Wyberg T., \& Leavitt, S. (2009). Fraction Operations \& Initial Decimal Ideas: Curriculum Module.

Downloaded from: http://www.cehd.umn.edu/ci/rationalnumberproject

Gagne, F. (2015). From genes to talent: The DMGT/CMTD perspective, Revista de Educacion, 368, 12 39. DOI: 10.4438/1988-592X-RE-2015-368-289.

Gall, M.D., Gall, J.P., Borg, W.R. (2010). Applying Educational Research. Boston: Allyn and Bacon Inc.

Harel, G. (2008a). What is Mathematics? A Pedagogical Answer to a Philosophical Question. In Gold, B. \& Simons, R.A. (Eds.): Proof and Other Dilemmas: Mathematics and Philosophy (pp.265-290). Washington, DC: MAA.

Harel, G. (2008b). DNR perspective on mathematics curriculum and instruction, Part I: focus on proving. ZDM Mathematics Education, 40, 487-500

DOI: $10.1007 / \mathrm{s} 11858-008-0104-1$

Hong, E. and Aqui, Y. (2004) Cognitive and motivational characteristics of adolescents gifted in mathematics: Comparison among students with different types of giftedness. Gifted Child Quarterly, 48, 191-201. https://doi.org/10.1177/001698620404800304.

Krutetskii, V. A. (1976). The psychology of mathematical abilities in schoolchildren (Translation from Russian: J Teller Trans J Kilpatrick \& I. Wirszup Eds.). United States: The University of Chicago Press.

Kurnaz, A. (2018). Examining Effects of Mathematical Problem-Solving, Mathematical Reasoning and Spatial Abilities on Gifted Students' Mathematics Achievement. World Scientific Research, 5 (1), 37-43. DOI: 10.20448/journal.510.2018.51.37.43

Leikin, R. (2011). The education of mathematically gifted students: Some complexities and questions. The Mathematics Enthusiast, 8 (1), 167-188.

Mann, E. L. (2006). Creativity: The essence of mathematics. Journal for the Education of the Gifted, 30 (2), 236-262. DOI: 10.4219/jeg-2006-264.

NCTM. (1989). Curriculum and Evaluation Standards for School Mathematics. Reston, VA: NCTM

Piirto, J. (2007). Talented children and adults: Their development and education 2nd ed. United States: Prufrock Press.

Presmeg, N. C. (1986). Visualization and mathematical giftedness. Educational Studies in Mathematics, 17 (3), 297-311. https://doi.org/10.1007/BF00305075.

Renzulli. (1986). The three-ring conception of giftedness: A developmental model for creative productivity. In R. J. Sternberg \& J. E. Davidson (Eds.): Conception of giftedness. United States: Cambridge University Press.

Sheffield, L. J. (1999). Developing mathematically promising students. United States: National Council of Teachers of Mathematics.

Singer, F. M., Sheffield, L.J., Freiman, V., and Brandl, M. (2016). Research On and Activities For Mathematically Gifted Students ICME-13 Topical Surveys. Switzerland: Springer

Sriraman, B. (2003). Mathematical giftedness, problem solving, and the ability to formulate generalization: the problem solving experience of four gifted students?. The Journal of Secondary Gifted Education, 14 (3), 151-165.

Yin, R. K. (2009). Case study research: design and methods (4th Ed.). Thousand Oaks, CA: Sage. 